IJLRES - International Journal on Language, Research and Education Studies

ISSN: 2580-6777 (p); 2580-6785 (e)

DOI: $10.30575 / 2017 /$ IJLRES-2018091201

Vol. 2, No. 3, 2018

Page: $312-321$

\title{
TEACHER COMPETENCY ON LEARNING AL-QURAN IN RAUDHATUL ATHFAL AT MEDAN
}

\author{
Halimatusssa' diyah Lubis \\ Postgraduate Studies, State Islamic University of North Sumatra, Indonesia \\ Halimatussa'diyahubis@gmail.com \\ Saiful Akhyar Lubis \\ Postgraduate Studies, State Islamic University of North Sumatra, Indonesia \\ saifulakhyar@uinsu.ac.id \\ Fachruddin Azmi \\ Postgraduate Studies, State Islamic University of North Sumatra, Indonesia \\ fachruddinazmi@uinsu.ac.id
}

\begin{abstract}
This study aims to determine the activities of the Ministry of Religious Affairs Office of Medan City in improving teacher competence in teaching Al-Qur'an, planning the learning of the teacher Raudhatul Athfal in teaching Al-Qur'an, the learning method that the teacher does in teaching Al-Qur'an, the obstacles faced by the teacher in teaching Al-Qur'an, and knowing the efforts conducted by the teacher in overcoming obstacles in teaching Al-Qur'an at Raudhatul Athfal in Medan City. Data collection techniques used were interviews, observation, documentation studies. Data management consists of data reduction, data display / data presentation, data analysis, techniques to ensure the validity of research results. The results of the study revealed that the activities of the Ministry of Religion of Medan City to improve the competence of teachers in teaching the Koran at Raudhatul Athfal Medan City are programs to improve teacher education qualifications, integrated competency-based training programs, education supervision programs and teacher empowerment programs through teacher learning planning Raudhatul Athfal in teaching The Koran at the Raudhatul Athfal City of Medan is a plan for organizing or organizing learning materials that will be given / taught to students consisting of plans for the preparation of the Semester Program (PROMES), Weekly Learning Implementation Plans (RPPM), Daily Learning Implementation Plans (RPPH), and Standard Operating Procedure (SOP).
\end{abstract}

Keywords : Teacher Competency, Learning Al-Qur'an. Raudlatul Athfal

\section{Introduction}

In the last five years, the condition of Raudhatul Athfal's teacher competence in Medan City, especially in teaching Qur'anic subjects has decreased. Based on the results of observations made on several Raudhatul Athfal in Medan, it was found that the ability of the teacher Raudhatul Athfal in teaching the Koran was still lacking. Observations on 
Raudhatul Athfal Ulumul Quran Jl. Happy Model Example Medan Area and Raudhatul Athfal Iqra Jl. PLTU Sicanang Belawan including not fulfilling properly.

Raudhatul Athfal Ulumul Quran Jl. Happy Model Example Medan Area and Raudhatul Athfal Iqra Jl. Sicanang Belawan power plant is given the authority to teach subjects of the Qur'an, while its competence in the mastery of reading the Qur'an and mastery of methodology in teaching the Qur'an is very minimal. In a sense, some of the teachers at Raudhatul Athfal have not been able to exemplify the reading of the Qur'an according to the Tajwid and Fashahah Sciences to be displayed in Tilawatil Qur'an as expected.

The next problem is that there are some teachers of Raudhatul Athfal who do have competencies that are in accordance with the expected in mastering the Qur'an reading by using various songs, but they lack the right and proper method in implementing the learning process of teaching the Qur'an in the classroom. As a result, many of the students of Raudhatul Athfal are also less able to understand and master the material presented.

According to Thalib, the competence of the teacher in the learning of the Qur'an for children, is first emphasized in the stipulation of pronouncing the letters commonly referred to as makhorijul. After the determination to read letters, fluency is increased by reading words and sentences, after which it is improved in the recitation of recitation. Thus, the teaching of the Qur'an for children can reach its needs to the level of reading and reading skills. Reading the Qur'an with tajwid including part of our efforts to glorify the Qur'an. Rasulullah SAW always recommends that we should read the Qur'an with tajwid $^{1}$

Increasing the potential and ability of teachers Raudhatul Athfal in the mastery of reading the Qur'an and mastery in learning methods of the Qur'an is very important and very essence especially with the competence owned, because it will be able to determine the development of student competence Raudhatul Athfal in the future as the successor generations qurani. Based on this condition, the authors are interested to conduct research and set it in the title of dissertation of Teacher Competence in Learning Alquran in Raudhatul Athfal Medan City.

1M. Thalib, 50 Pedoman Mendidik Anak Menjadi Anak Shaleh, (Bandung: Irsyad baitussalam, 1991), p. 


\section{LITERATURE REVIEW}

Teachers are implementers of education in certain places. Teachers must really be able to influence their students and teachers should be broad-minded. From the description above shows that the teacher is one of the influential person in the implementation of teaching and learning process. The teacher is the one who gives knowledge to the students. ${ }^{2}$

The teacher is the one who is responsible for educating the students. Thus the teacher is a profession that demands special skills. The teacher's job as a profession requires the teacher to develop self-professionalism in accordance with the development of science and technology. Educating, teaching and training students is a teacher's job as a profession. Teacher's job as an educator means continuing and developing science and technology to the students. The teacher's job as a trainer means developing skills and applying them in life, for the future of students. ${ }^{3}$

Teachers dealing with students is at the time of teaching and learning process takes place. A teacher should have a good performance especially during the learning process takes place. Teachers are expected to have a sufficient science appropriate field, clever communicate nurturing and become a good learning for students to the body and grow into adulthood. According to Sukadi, as a professional, teachers have five main tasks; plan learning, implementation of learning, and evaluation of learning, follow up learning outcomes, and conduct guidance and counseling. ${ }^{4}$

Competence is the authority of each individual to perform the task or make decisions in accordance with his role in the organization relevant to the expertise, knowledge, and ability possessed. Sagala also argued that competence is a set of knowledge, skills, and behavior that must be owned, experienced, mastered and actualized by teachers in performing professional duties. ${ }^{5}$

Muhibbinsyah argued that every prospective teacher and professional teacher is expected to understand the characteristics (characteristics) of his personality that is required as a model of his students. Constitutionally, teachers / educators at each formal

\footnotetext{
2003), p. 31.

2Syaipul Bahri Djamarah, Guru Dan Anak Didik Dalam Interaksi Edukatif (Jakarta : Rineka Cipta,

3Syaiful Bahri Jamarah, Guru dan Anak Didik dalam Interaksi Edukatif, p. 37.

${ }^{4}$ Sukadi, Guru Powerful Guru Masa Depan, (Bandung: Kolbu, 2001) cet. 1, p 26

p.342

5Saiful Sagala, Kemampuan Profesional Guru dan Tenaga Kependidikan (Bandung : Alfabeta, 2012),
} 
education level must have a qualification unit (required expertise) and certification (read: teaching authority) generated by accredited higher education (Article 42 paragraph 1 and 2 of the Sisdiknas Law 2003). Characteristics of personality related to the success of teachers in wrestle his profession include: 1) cognitive flexibility, 2) psychological openness. ${ }^{6}$

Based on language, the word of the Qur'an is taken from the verb "qoroa" means "He has read". Then this word means reading. ${ }^{7}$ This means that the Qur'an must be read by all Islamic communities. The naming of the revelation with the Qur'an gives the understanding that it is stored in the human chest given the name of the Qur'an itself comes from the word قرأة and in qiraah contained the meaning of always remember. ${ }^{8}$

The Qur'an is etymologically derived from the word قراء يقراء قراءة which means something to read (المقرو). Thus, the meaning of the Qur'an in lughawi is something to read. Another opinion says that the meaning of the Qur'an is similar to the form of masdar (form of noun), ie القراءة which means gather and collect (الضم و الجمع).

The importance of reading it to man, explained M. Quraish Shihab that is so, the command of reading is the most valuable command that can be given to mankind. Because, reading is the path that leads humans to reach the level of humanity is perfect. Thus, it is not an exaggeration to say that "reading" is a key condition for building civilization. And if it is acknowledged that the more widely read the higher the civilization, and vice versa. ${ }^{9}$

The method comes from the Latin "meta" which means through, and "hodos" which means path or to or way to. In Arabic the method called "tariqah" means road, way, system, or order in doing something. Meanwhile, according to the term is a system or a way that set a goal. ${ }^{10}$

In learning the Qur'an must also use methods whose purpose is certainly to be able to facilitate the learners to be able to read Alqu'an. To facilitate the teaching of the Qur'an, at least some of its teaching methods should be known. In terms of teaching

6Muhibbinsyah, Psikologi Pendidikan (Jakarta : Rineka Cipta, 2010), h. 225.

${ }^{7}$ Moenawar Cholil, Kembali Kepada Alquran dan As-Sunnah, (Jakarta: Bulan Bintang, 1991), p. 201.

8Subhi As-Shalih, Membahas Ilmu-Ilmu Alquran, (Jakarta: Firdaus, 1993), h. 13.

${ }^{9}$ M. Quraish Shihab. Membumikan Alquran, (Fungsi dan Peran Wahyu dalam Kehidupan Masyarakat), Bandung: Mizan, 2009), h. 170.

${ }^{10}$ Nur Uhbiyati, Ilmu Pendidikan Islam (IPI) Untuk IAIN, STAIN, PTAIS, cet.2 (Bandung : Pustaka Setia, 2005), h. 123 
methods of the Qur'an there are four methods, among others: the method of SAS, Iqro ', Al-Barqi and Al-Banjari.11

As for what is meant by adab reading the Koran is an activity / activity of seeing and understanding in accordance with the rules that exist in the Koran and reciting the words of Allah (Alquran) verbally which is a miracle revealed to the Prophet Muhammad by means of the angel Gabriel to us mutawatir and read it is worship. There are several manners that must be considered, held and guarded, before and while reading the Koran to be useful, blessed and able to produce fruit in the form of tadabbur, always istiqomah in doing it and according to the Prophet Muhammad and his companions do.

Adab reciting the Koran as agreed by the cleric is improving the voice while reading. The Qur'an is certainly a beautiful and even beautiful reading. However, a beautiful voice will add to its beauty so that it moves the heart and shakes the heart. ${ }^{12}$ And boasting its readings with the melodious songs. ${ }^{13}$

\section{METHODOLOGY}

This type of research is qualitative research. According to Strauss and Corbin, qualitative research is a type of research that results in discoveries that cannot be achieved by using statistical procedures or other means of quantification. ${ }^{14}$ One reason researchers use a qualitative approach is that qualitative research can uncover phenomena that occur, so as to find and understand what is hidden behind the phenomenon.

The implementation of qualitative research is to know the hidden meaning, to understand social interaction, to develop theory, to verify the truth of the data, and to examine the history of development. Given that this study aims to understand and interpret various phenomena that exist or that occur in reality as a characteristic of qualitative research, then in this study is to determine the competence of teachers in learning the Qur'an in Raudhatul Athfal at Medan.

${ }_{11}$ M. Thalib, 50 Pedoman Mendidik Anak Menjadi Shahih, (Bandung: Irsyad Baitussalam, 1996), h. 81. ${ }^{12}$ Yusuf Al-Qaradhawi, Berinteraksi Dengan Al-Qur'an, (Jakarta: Gema Insan, 1999), p. 233.

${ }^{13}$ Abdul Majid Khon, Praktikum Qira'at Keanehan Membaca Al-Qur'an Qira'at Ashim dari Hafash, Cet. ke-1, (Jakarta: Amzah, 2008), p. 38

${ }^{14}$ Anselm Strauss \& Juliet Corbin, Dasar-dasar Penelitian Kualitatif, Terjemahan : Andi Hakim (Yogyakarta: Pustaka Pelajar, 2003), p.69. 
Data collection in this study was conducted with 3 (three) techniques commonly used in qualitative research, namely interviews, observation, and document review. Data analysis is the process of arranging data sequences, organizing them into a pattern, category and description unit so that themes can be found and hypotheses can be formulated as suggested by the data

Data analysis techniques use the techniques proposed by Miles and Huberman below: 15

1. Data reduction, is to make an abstraction of all data obtained from field records resulting from observation, interviews and document review. Data reduction is a form of data analysis that sharpens, expects important things, classifies, directs, discards what is not needed and organizes data so that it is systematic and can make meaningful conclusions.

2. Presentation of data, is a set of structured information that gives the possibility of drawing conclusions and taking action. The process of presenting this data reveals as a whole a group of data obtained so that it is easy to read and understand, the most frequently used for the presentation of data in qualitative research is narrative text. The data can illustrate how the competence of teachers in learning the Qur'an in Raudhatul Athfal Medan.

3. Conclusions, namely a complete, detailed and in-depth data structure based on data obtained from observations, interviews, and document review.

\section{FINDINGS AND DISCUSSION}

The guidance of teacher competence in Raudhatul Athfal conducted by the Ministry of Religious City of Medan can be stated as follows:

1) Teacher Education Improvement Program

Teacher qualification improvement program is a program to improve the quality of education for teachers intended for teachers of religious education who do not have a minimum education qualification of S-1 to follow education S-1 or S-2 teacher education. This program is a continuation program of study in the form of learning tasks for teachers who meet the provisions that apply.

${ }^{15}$ Mattew B. Miles dan A. Michael Huberman, Analisis Data Kualitatif (terj. Tjetjep Rohendi Rohidi, Jakarta: UI-Press, 2002), p. 16-19. 
2) Competency-Based Integrated Training Program.

Competence-based integrated training program is a training activity that refers to the guidance of the competencies to be achieved and required by the teacher so that the contents or training materials provided are the combined or integrated fields of science resources of training materials that are fully required to achieve teacher competence. In order to improve the professionalism of teachers it is necessary to do intensive training and upgrading in teachers. Training required is training tailored to the needs of teachers is training that refers to the demands of teacher competence.

\section{3) Education Supervision Program.}

Ministry of Religious Affairs of Medan City in the implementation of supervision to increase the competence of teachers supervisory perform

4) RA Teacher Empowerment Program.

The Teachers Working Group is a professional forum for teachers in a district / city / school / school cluster, whose working principle is a reflection of activities by, for and from teachers of all schools. A non-structural organization that is independent, based on kinship, and does not have a hierarchical relationship with other institutions.

The preparation of the learning plan is a design for the teacher Raudhatul Athfal to carry out learning activities. Plan of learning implementation of course before the implementation of learning activities implemented. The learning plan prepared by the teacher Raudhatul Athfal must refer to the characteristics of children, namely age, social culture and individual needs of children. Therefore for teachers Raudhatul Athfal in preparing the implementation plan of learning should pay attention to the goal, they are;

1) Support the achievement of Basic Competencies and Core Competencies

2) Support the successful management of meaningful learning

3) Directing teachers in preparing necessary tools and materials

4) Directing teachers to build the attitudes, knowledge and skills the child expects Quran learning method that is implemented to children in Raudhatul Athfal Medan City by doing the steps namely:

1) Introduction of letters, teachers teach letters from alif to ya by memorizing one by one the hijaiyah letters followed by the students and memorizing them slowly, and writing them down in letters that are easily understood by children. So that 
young children in addition to fast memorization, they will also always remember the letters that are pronounced.

اب ت ث ج For example

2) Introduction of harakah, by writing the top, bottom, and breadfruit lines, and inviting them to memorize together

ان ان ب انب ت ت ت ث ث ث ث ج ج ج

3) Splicing letters, ie explaining and teaching the letters connected to each other:

For example: ت ب ق ب فل

4) Introduction of short lengths, ie explaining which readings are read long and readings are short read.

For example: لت كت ت

5) Introduction of sentences, ie explaining fragments of Arabic words or words quoted from the Qur'an.

For example: شفاعة فا عامه

6) The introduction of the waqaf sign, ie explaining the stop signs (waqaf), such as the mandatory stop when there is a letter p) waqaf prevalent); should not stop at the letter $\vee$, and so on

Constraints in the implementation of learning the Qur'an in Raudhatul Athfal Medan is still experiencing constraints of low quality teachers and limited facilities / infrastructure for learning activities. Other problems are monotonous and teacherfocused learning, lack of teaching aids and handbooks for teaching materials. These issues should be a major concern to start improving the implementation of education for early childhood.

Some efforts that have been done in overcoming obstacle of learning of Alquran in Raudhatul Athfal Medan City is by improving teacher competence through implementation of learning skill training of Qur'an. Besides, it is also an effort to fulfill the suggestions and infrastructure needed during the implementation of learning the Qur'an in Raudhatul Athfal Medan City

\section{CONCLUSION}

1. Activities of the Ministry of Religion of Medan City to improve the competence of teachers in teaching the Koran at the Raudhatul Athfal City of Medan, namely programs to improve teacher education qualifications, integrated competency- 
based training programs, education supervision programs and empowerment programs for RA teachers.

2. Planning the learning of the teacher Raudhatul Athfal in teaching the Koran at the Raudhatul Athfal in the City of Medan, namely the plan of preparation or organization of learning materials that will be given / taught to students consisting of plans for the preparation of the Semester Program (PROMES), Weekly Learning Implementation Plans (RPPM), Daily Learning Implementation Plan (RPPH), and Standard Operating Procedure (SOP)

3. The Qur'anic learning method used by the teacher in general is the iqro method which consists of letter recognition, harakah recognition, letter joining, short length recognition, and sentence recognition, waqaf sign recognition.

4. Constraints in the implementation of Qur'anic learning are the low quality of teachers and the limited facilities / infrastructure for the learning activities of the Koran at the Raudhatul Athfal in Medan City.

5. The teacher's efforts in overcoming obstacles in teaching the Koran at Medan's Raudhatul Athfal by improving teacher competency through the implementation of Qur'anic learning skills training and fulfillment of suggestions and infrastructure needed during the implementation of the Koran learning at Raudhatul Athfal Medan City.

\section{BIBILIOGRAPHY}

Al-Qaradhawi, Yusuf, Berinteraksi Dengan Al-Qur'an, Jakarta: Gema Insan, 1999.

Anselm Strauss \& Juliet Corbin, Dasar-dasar Penelitian Kualitatif, Terjemahan : Andi Hakim, Yogyakarta: Pustaka Pelajar, 2003.

As-Shalih, Subhi, Membahas Ilmu-Ilmu Alquran, Jakarta: Firdaus, 1993.

Cholil, Moenawar, Kembali Kepada Alquran dan As-Sunnah, Jakarta: Bulan Bintang, 1991.

Djamarah, Syaipul Bahri, Guru Dan Anak Didik Dalam Interaksi Edukatif, Jakarta : Rineka Cipta, 2003.

Hasanuddin. Anatomi Alquran, Perbedaan Qiroat dan Pengaruhnya Terhadap Istinbath Hukum dalam Alquran, Jakarta: Grafindo Persada, 1995.

Khon, Abdul Majid, Praktikum Qira'at Keanehan Membaca Al-Qur'an Qira'at Ashim dari Hafash, Jakarta: Amzah, 2008. 
Mattew B. Miles dan A. Michael Huberman, Analisis Data Kualitatif, terj. Tjetjep Rohendi Rohidi, Jakarta: UI-Press, 2002.

Muhibbinsyah, Psikologi Pendidikan, Jakarta : Rineka Cipta, 2010.

Purba, Sukarman, Kinerja Ketua Jurusan Di Perguruan Tinggi, Teori, Konsep dan Korelatnya, Yogyakarta: Presindo, 2009.

Sagala, Saiful, Kemampuan Profesional Guru dan Tenaga Kependidikan, Bandung : Alfabeta, 2012.

Shihab, M. Quraish,. Membumikan Alquran, (Fungsi dan Peran Wahyu dalam Kehidupan Masyarakat), Bandung: Mizan, 2009.

Sugiyono, Metode Penelitian Pendidikan, Pendekatan Kuantitatif, Kualitatif, dan RED, Bandung: Alfabeta, 2008.

Sukadi, Guru Powerful Guru Masa Depan, Bandung: Kolbu, 2001.

Sutisna, Oteng, Administrasi Pendidikan Dasar Teoritis Untuk Praktek Profesional, Bandung: Angkasa, 2003.

Thalib, M., 50 Pedoman Mendidik Anak Menjadi Anak Shaleh, Bandung: Irsyad baitussalam, 1991.

Uhbiyati, Nur, Ilmu Pendidikan Islam (IPI) Untuk IAIN, STAIN, PTAIS, Bandung: Pustaka Setia, 2005.

Veithzal Rivai dan Sylviana Murni, Education Management Analisis Teori dan Praktik, Jakarta: Rajawali Press, 2010. 